JKKP: Jurnal Kesejahteraan Keluarga dan Pendidikan

http://doi.org/10.21009/JKKP

DOI: doi.org/10.21009/JKKP.012.03

E-ISSN: 2597-4521

\title{
Hubungan Kelekatan Orang Tua dengan Anak terhadap Kecerdasan Emosional Remaja Laki-Laki di SMP
}

\author{
${ }^{1)}$ Asti Winarti, ${ }^{2)}$ Cholilawati, ${ }^{3)}$ Ari Istiany \\ 1,2,3)P rogram Studi Pendidikan Kesejahteraan Keluarga, \\ F akultas Teknik, Universitas Negeri I akarta \\ J In. Rawamangun Muka, J akarta Timur. 13220
}

\begin{abstract}
Abstrak
Penelitian ini bertujuan untuk mengetahui dan menganalisis hubungan antara kelekatan orang tua dengan anak terhadap kecerdasan emosional remaja laki-laki. Penelitian ini dilakukan di SMPN 2 Pagedangan Tangerang pada Januari-Juni 2014 dengan sampel 113 siswa. Metode penelitian yang digunakan yaitu metode survey dengan pendekatan korelasional. Uji prasyarat analisis menunjukkan bahwa data berdistribusi normal dan terjadi regresi yang linier. Hasil penelitian diperoleh koefisien korelasi Pearson Product Moment sebesar 0,46 yang menunjukan terdapat hubungan yang signifikan antara kelekatan orang tua dengan anak terhadap kecerdasan emosional remaja laki-laki. Berdasarkan koefisien determinasi ketahui bahwa kelekatan orang tua terhadap anak berkontribusi terhadap kecerdasan emosi remaja laki-laki sebesar $21,20 \%$. Hasil uji regresi diperoleh persamaan yang berart bahwa setiap kenaika satu satuan pada variabel kelekatan orang tua dengan anak akan diikuti dengan kenaikan kecerdasan emosional remaja laki-laki sebesar 0,60 pada konstanta 19,93.
\end{abstract}

Kata Kunci: kecerdasan emosi, kelekatan, remaja laki-laki

\section{Relationship Between Parents and Children Attachment and Emotional Intelligence of Male Adolescent In J unior High School}

\begin{abstract}
The purpose of this study are to determine the relationship between parents and children attachment and emotional intelligence of male adolescent in junior high school. The study was conducted at the SMPN 2 Pagedangan Tangerang, during J anuary 2014 until J une 2014. Research methods using survey methods with a correlational approach. The study population was all male students of grade VIII SMPN 2 Pagedangan Tangerang who lived with both parents or only one parent, the research sample was taken by using saturated sampling method, where all the population were sampled in the study, with a total of 113 students. The result of regression equation is $\hat{Y}=19,93+0,60 X$. The result of normality test is normal. The result of linearity test with a linierity regression is linier. Hypothesis test results that test significance of the regression is significant. The correlation coefficients of Pearson Product Moment generating rxy $=0.46$. The result of the study and test hypothesis about the relationship are obtained that there is a positive relationship between parents and children attachment and emotional intelligence of male adolescent students of grade VIII SMPN 2 Pagedangan Tangerang. The coefficient of determination obtained by $21.20 \%$ indicates the magnitude of the emotional intelligence of male adolescent that influenced by parents and children attachment.
\end{abstract}

Keywords: Emotional Intelligence, Attachment, Male Adolescent 


\section{PENDAHULUAN}

Masa remaja memiliki begitu banyak makna, di masa ini individu mendapatkan banyak tekanan serta tuntutan dari lingkungan sekitarnya namun sekaligus pengecualian atas perilaku yang dilakukan. Masa remaja dimaknai sebagai periode pencarian identitas, periode peralihan dan perubahan, periode usia bermasalah serta periode usia yang menimbulkan ketakutan. Masa remaja merupakan rentan waktu peralihan dimana individu beranjak dari anak-anak hingga menjadi dewasa. Pada masa ini remaja mengalami begitu banyak kebimbangan, hanya dari faktor internal dirinya namun juga faktor eksternal atau lingkungannya.

Remaja secara psikologis dan sosial berada dalam situasi yang peka dan kritis. Peka terhadap perubahan dan mudah terpengaruh oleh berbagai perkembangan disekitarnya. Hal ini menyebabkan remaja mudah mengalami masalah terkait dengan kecerdasan emosional. Dikatakan, bahwa remaja saat ini lebih kesepian, pemurung, kurang menghargai sopan santun, lebih gugup mudah cemas dan lebih meledak- ledak (implusif dan regresif). Selain itu remaja yang memiliki masalah dalam kecerdasan emosi akan sulit belajar, bergaul, mengendalikan diri, mengontrol emosi serta mudah terpengaruh terhadap perilaku-perilaku negatif.

Begitu pula yang terdapat pada lingkungan sekitar Sekolah Menengah Pertama Negeri (SMPN) 2 Pagedangan. SMPN 2 Pagedangan berada pada lingkungan komplek perumahan. Kondisi emosional remaja pada lingkungan ini kurang baik, hal tersebut ditunjukan dengan adanya perkelahian antar kelompok yang terjadi di lingkungan tersebut. Menurut warga sekitar, perkelahian tersebut terjadi diawali dari kesalahpahaman dari anggota kelompok masing- masing.

Hasil wawancara dengan Ketua RT 002 dan RW 05 di lingkungan komplek perumahan Medang Lestari menyebutkan bahwa perkelahian antar kelompok ini awalnya terjadi hanya karena saling ejek antar beberapa anak, namun hal itu pun berkembang dan melibatkan perkelahian antar kelompok. Perkelahian tersebut terjadi di sekitar bulan Maret, namun ternyata menurut kesaksian dari anggota kelompok yang ikut berkelahi hal tersebut sudah terjadi dari bulan Januari. Kelompok yang bekelahi tersebut kurang lebih berjumlah 8-12 anak yang masih duduk di sekolah dasar dan sekolah menengah pertama. Ketua RW lingkungan tersebut juga mengatakan bahwa perkelahian tersebut tidak menyebabkan luka yang serius untuk kedua belah anggota kelompok, maka untuk menyelesaikan permasalahan ketua RW 05 hanya mengumpulkan orang tua dari anak-anak tersebut dan melakukan musyawarah dengan disaksikan oleh RT setempat.

Mayoritas remaja laki-laki yang duduk di sekolah menengah pertama pada lingkungan tersebut bersekolah di SMPN 2 Pagedangan. Pihak sekolah menyatakan bahwa memang benar terdapat beberapa siswa mereka yang terlibat dalam perkelahian kelompok tersebut. Selain masalah perkelahian antar kelompok, pihak sekolah juga mengungkapkan beberapa permasalahan mengenai kenakalan remaja yang ada di sekolah tersebut, antara lain pemerasan yang dilakukan antar teman dan antara senior kepada juniornya, dan permasalahan absensi, dimana siswa mengaku bersekolah kepada orang tua namun siswa tidak hadir di sekolah. Pihak sekolah mengatakan bahwa siswa laki-laki lebih banyak melakukan kenakalan-kenakalan tersebut dibandingkan dengan siswi perempuan, dan kebanyakan kenakalan yang dilakukan siswa laki-laki berhubungan dengan agresifitas.

Laki-laki khusus yang masih berada pada masa remaja, cenderung kurang mampu dalam mengekspresikan emosi seperti hal nya remaja perempuan, hal ini menunjukan bahwa remaja laki-laki cenderung memiliki ketidakmatangan emosi jika dibandingkan remaja perempuan (Santrock, 2003: 376). Sedangkan menurut teori biologi, secara umum laki-laki cenderung lebih agresif dan kurang mampu mengelola emosinya disebabkan karena hormon testosteron laki-laki lebih tinggi dibandingkan perempuan, dan hormon testosteron dipercaya dengan pembawa sifat agresif (Sarwono, 2002), dan tidak terkecuali pada remaja laki-laki pada khususnya.

Salah satu faktor pembentukan emosional remaja yang sangat mempengaruhi adalah lingkungan keluarga terutama orang tua. Dalam hal ini keluarga atau orang tua mempunyai pengaruh besar terhadap suasana psikis anggotanya, termasuk dalam kematangan emosi remaja. Orang tua dalam keluarga bertugas menunjang pertumbuhan dan perkembangan yang sehat bagi 
anaknya dengan memenuhi kebutuhan emosional khususnya terhadap anak remaja. Hubungan anak dan orang tua merupakan sumber emosional dan kognitif bagi anak. Hubungan tersebut dapat menjadi sarana bagi anak untuk belajar mengenai lingkungan maupun kehidupan sosial disekitarnya.

Bapak Agus dari pihak sekolah juga menyatakan bahwa saat ini orang tua masih banyak yang hanya menuntut dan memberikan lebel kepada anak tanpa melihat kondisi atau kemampuan anak mereka. Orang tua menuntut anak untuk sesuai dengan keinginan mereka dan apabila anak tidak dapat memenuhi hal tersebut orang tua langsung memberikan lebel bahwa anak mereka bukanlah anak yang baik. Meskipun terkadang orang tua melakukan hal tersebut tanpa disengaja, tentu akan berpengaruh terhadap anak.

Keterkaitan antara emosional remaja dengan keluarga khususnya orang tua dapat terlihat dari kelekatan yang terjalin di antara keduanya. Kelekatan merupakan suatu ikatan emosional yang kuat yang dikembangkan anak melalui interaksinya dengan orang yang mempunyai arti khusus dalam kehidupannya, biasanya orang tua. Dengan kata lain kelekatan dapat berarti afeksi yang kuat antara anak dan figur lekatnya (orang tua). Remaja yang memiliki hubungan kelekatan yang sehat dan aman dengan orang tuanya dapat membantu remaja dari kecemasan dan kemungkinan perasaan tertekan atau ketegangan emosi yang berkaitan dengan transisi dari masa kanak-kanak menuju dewasa (Santrock, 2003: 194).

Berdasarkan uraian di atas dapat ditarik kesimpulan bahwa kelekatan yang merupakan penjabaran mengenai hubungan intim orang tua dan anak (remaja) dapat mempengaruhi kecerdasan emosi remaja khususnya remaja laki- laki yang memiliki kecenderungan lebih besar dalam melakukan kenakalan-kenalakan remaja. Kelekatan orang tua dan anak (remaja) sebagai salah satu faktor pembentuk kecerdasan emosi dapat membantu remaja melewati masa transisinya hingga mencapai dewasa.

Pembatasan masalah dalam penelitian ini dibatasi pada hubungan antara kelekatan orang tua dengan anak terhadap kecerdasan emosional remaja laki-laki yang tinggal bersama orang tua atau pun salah satu orang tua (kelas VIII/2 Sekolah Menengah Pertama).

\section{METODE PENELITIAN}

Penelitian ini dilakukan di Sekolah Menengah Pertama Negeri (SMPN) 2 Pagedangan yang beralamatkan di Jl. Perum Medang Lestari, Kec. Pagedangan, Kab. Tangerang, Banten. Waktu penelitian dilakukan selama dari Januari 2014 sampai dengan Juni 2014.Metode yang diterapkan pada penelitian ini adalah metode deskriptof dengan pendekatan survey.

Populasi penelitian ini adalah seluruh siswa laki-laki kelas VIII SMPN 2 Pagedangan Tangerang yang tinggal bersama orang tua atau salah satu orang tua, yaitu berjumlah 113 siswa. Teknik pengambilan sampel dilakukan dengan teknik sampling jenuh sehingga siswa laki-laki kelas VIII SMPN 2 Pagedangan Tangerang yang masih memiliki orang tua baik ayah maupun ibu dan tinggal bersama yang berjumlah 113 seluruhnya dijadikan sebagai sumber data.

Instrumen yang digunakan untuk pengumpulan data dalam penelitian ini berupa kuesioner dan angket untuk menjabarkan karakteristik responden, mengukur kelekatan orang tua dengan anak dan kecerdasan emosional remaja laki-laki.

\section{HASIL DAN PEMBAHASAN}

Hasil data penelitian terbagi menjadi dua, yaitu hasil data karakteristik responden dan hasil data variabel kelekatan orang tua dengan anak dan kecerdasan emosional remaja laki-laki.

Dalam penelitian ini mayoritas remaja laki- laki masih tinggal bersama kedua orang tua, maka berdasarkan status tinggal bersama terdapat kemungkinan remaja laki-laki bisa terhindar dari dampak yang terjadi pada keluarga yang hanya memiliki salah satu orang tua saja. 
Usia ayah mayoritas berada pada rentang usia 43-46 tahun. Status pekerjaan ayah myoritas memiliki pekerjaan sebagai pegawai swasta. Dengan umumnya dengan pendapatan ayah di antara $\mathrm{Rp} 1.500 .000-\mathrm{Rp} 2.500 .000$ yang termasuk dalam kategori pendapatan sedang menurut BKKBN.

Umumnya usia ibu dari responden terbanyak pada rentang usia 42 - 45 tahun yang umumnya tidak bekerja atau hanya sebagai ibu rumah tangga.

\section{Deskripsi Kelekata Orang Tua Terhadap Anak}

Aspek atau indikator yang memiliki persentase sumbangan terbesar yaitu aspek atau indikator kepercayaan dan hasil perhitungan menunjukan bahwa aspek atau indikator kepercayaan antara remaja laki-laki kelas VIII SMPN 2 Pagedangan Tangerang dengan orang tuanya berada antara kategori kurang baik dan cukup baik, tetapi lebih mendaki cukup baik. Kepercayaan menurut Armsden dan Greenberg (Rosdiana, 2011), dapat didefiniskan sebagai perasaan aman dan keyakinan terhadap orang lain yang akan memenuhi kebutuhannya, dalam hal ini responden remaja laki-laki kelas VIII SMPN 2 Pagedangan Tangerang yang masih berada dalam fase remaja awal tentu saja belum dapat terlepas dari ketergantungannya akan orang tua untuk memenuhi kebutuhannya. Indikator kepercayaan antara orang tua dengan anak tersebut dapat terlihat dari adanya kepedulian orang tua terhadap anak disaat anak mengalami kesulitan, penerimaan terhadap diri anak apa adanya, mendukung keputusan- keputusan yang telah dibuat oleh anak dan akan selalu bertanya alasan mengapa anak merasa marah akan sesuatu terlebih dahulu terhadap anak.

Selanjutnya aspek atau indikator komunikasi, bila dibandingkan dengan indikator kepercayaan dan keterasingan komunikasi memiliki sumbangan persentase terkecil terhadap kelekatan orang tua dengan anak, akan tetapi berdasarkan hasil persentase perhitungan skor ratarata didapat bahwa komunikasi antara remaja laki-laki kelas VIII SMPN 2 Pagedangan Tangerang dengan orang tuanya berada antara kategori kurang baik dan cukup baik, tetapi masih lebih mendekati kategori yang cukup baik. Komunikasi antara orang tua dengan anak khususnya dengan remaja laki-laki sering kali menemui kendala, sehingga tujuan untuk melakukan komunikasi yang baik tidak tercapai. Kendala komunikasi antara orang tua dengan remaja khususnya remaja laki-laki menurut BKKBN dapat disebabkan karena ada beberapa kecenderungan yang dilakukan orang tua ketika berkomunikasi dengan remaja, diantaranya yaitu orang tua lebih banyak berbicara daripada mendengarkan, selalu merasa lebih tahu karena merasa memiliki pengalaman yang lebih, tidak berusaha untuk mendengarkan terlebih dahulu apa yang sedang terjadi dan dialami oleh remaja, tidak memberi kesempatan remaja untuk memberikan pendapat serta tidak mencoba menerima dahulu kenyataan yang dialami oleh remaja dan memahaminya.

Terakhir aspek atau indikator keterasingan. Berdasarkan hasil persentase perhitungan skor rata-rata didapat bahwa keterasingan antara remaja laki-laki kelas VIII SMPN 2 Pagedangan Tangerang dengan orang tuanya berada antara kategori kurang baik dan cukup baik, tetapi masih lebih mendekati kategori yang cukup baik. Keterasingan sendiri berhubungan dengan menghindarnya figur lekat dan penolakan terhadap individu (Rosdiana, 2011). Keterasingan dari kasih sayang dan perhatian orang tua dapat menimbulkan rasa benci dalam diri remaja. Remaja laki-laki yang mengalami banyak permasalahan dalam periode tersebut seharusnya lebih banyak mendapatkan perhatian serta dorongan dari orang tua. Namun terkadang perhatian dan dorongan yang dilakukan oleh orang tua dapat berdampak buruk apabila hal tersebut dilakukan secara berlebihan atau cenderung memaksakan kehendak orang tua, tanpa memberikan peluang bagi remaja untuk mengembangkan keinginannya yang wajar, maka anak akan menjadi terasing dari hak untuk menyatakan keinginannya, remaja merasa dirinya tidak dimengerti oleh orang tuanya sendiri (Ancok, 2004). 


\section{Deskripsi Kecerdasan Emosi Anak Laki-Laki}

Indikator mengenali emosi diri sendiri terlihat dari bagaimana anak dapat dengan pasti mengetahui apa yang dia rasakan tanpa merasa bimbang, serta dapat dengan pasti tahu apa yang seharusnya dia ucapakan kepada orang lain mengenai perasaannya. Maka dapat disimpulkan bahwa indikator mengenali emosi diri merupakan indikator dominan dibandingkan dengan dua indikator lainnya, yaitu indikator mengendalikan emosi diri dan mengenali emosi orang lain (empati). Hasil penelitian menunjukan bahwa pengenalan emosi remaja laki-laki SMPN 2 Pagedangan Tangerang berada antara kategori kurang baik dan cukup baik, tetapi lebih mendekati kategori cukup baik. Mengacu pada Goleman (2003), mengenali emosi diri merupakan aspek kunci dari kecerdasan emosional, ketidakmampuan untuk mencermati perasaan sesungguhnya membuat individu berada dalam kekuasaan perasaan, maka dari itu aspek atau indikator tersebut menjadi indikator yang paling dasar dan penting bagi kecerdasan emosional seseorang. Indikator mengenali emosi diri sendiri terlihat dari bagaimana anak dapat dengan pasti mengetahui apa yang dia rasakan tanpa merasa bimbang, serta dapat dengan pasti tahu apa yang seharusnya dia ucapakan kepada orang lain mengenai perasaannya.

Aspek atau indikator yang memiliki persentase sumbangan terkecil dibandingkan kedua aspek atau indikator lainnya dalam membentuk kecerdasan emosional remaja laki- laki, yaitu aspek atau indikator mengelola emosi diri. Persentase sumbangan terkecil yang diberikan aspek atau indikator mengelola emosi diri sejalan dengan ciri khas perkembangan emosional remaja yang telah diutarakan oleh Ali \& Asrori (2012), khususnya pada rentang usia remaja laki-laki kelas VIII SMPN 2 Pagedangan Tangerang, bahwa pada masa ini biasanya remaja memiliki energi yang besar dan emosi yang berkobar-kobar, sedangkan pengendalian diri belum sempurna. Berdasarkan hasil perhitungan dalam penelitian menunjukan bahwa pengelolaan emosi remaja laki-laki SMPN 2 Pagedangan Tangerang berada antara kategori kurang baik dan cukup baik, tetapi masih lebih mendekati kategori cukup baik.

Aspek atau indikator terakhir yaitu aspek atau indikator mengenali emosi orang lain (empati). Hasil perhitungan dalam penelitian menunjukan bahwa pengenalan emosi orang lain (empati) remaja laki-laki SMPN 2 Pagedangan Tangerang berada antara kategori kurang baik dan cukup baik, tetapi masih lebih mendekati kategori cukup baik. Aspek atau indikator mengenali emosi orang lain merupakan dasar dari keterampilan pribadi (Goleman, 2003). Mengenali emosi orang lain (empati) pada remaja khususnya remaja laki-laki lebih tinggi sumbangannya bila dibandingkan dengan mengelola emosi diri, hal ini berkaitan dengan remaja yang memang pada umumnya memiliki begitu banyak konflik dan cenderung belum mampu dalam mengendalikan diri. Namun disamping itu pada periode ini, merupakan periode dimana remaja laki-laki tersebut mulai meluaskan hubungannya dengan lingkungan sosial disekitarnya, terlebih hubungannya dengan teman sebaya, sehingga remaja laki-laki dapat lebih mengenali emosi orang lain (empati).

\section{Hubungan Kelekatan Orang Tua Dengan Anak Terhadap Kecerdasan Emosional Remaja Laki-Laki}

Hasil perhitungan diperoleh rhitung sebesar 0,46. Apabila dikonsultasikan dengan rabel ada taraf signifikan $\alpha=0,05$ maka diperoleh rtabel yaitu 0,254 . Berdasarkan hal tersebut maka rhitung lebih besar dari rtabel $(0,46>0,254)$ (lampiran 21). Oleh karena itu dapat disimpulkan bahwa terdapat hubungan positif antara kelekatan orang tua dengan anak terhadap kecerdasan emosional remaja laki-laki kelas VIII SMPN 2 Pagedangan Tangerang.

Tingkat keberartian hubungan antara dua variabel di uji dengan uji "t" korelasi. Hubungan kedua variabel tersebut dinyatakan berarti jika thitung lebih besar dari ttabel. Berdasarkan perhitungan diperoleh thitung sebesar 6,15. Jika dikonsultasikan dengan ttabel pada taraf signifikan $\alpha=0,05$ dan $\mathrm{dk}=111$ maka diperoleh tabel 1,659. Dengan demikian thitung lebih besar dari ttabel $(6,15>1,659)$ (lampiran 22). Hal ini menunjukan bahwa kedua variabel mempunyai hubungan yang signifikan. Besarnya derajat hubungan kedua variabel dapat dilihat dari besarnya angka koefisien determinasi yaitu sebesar $21,20 \%$. Koefisien determinasi antara 
hubungan kelekatan orang tua dengan anak $(X)$ terhadap kecerdasan emosional remaja laki-laki (Y) sebesar $0,46^{2}=0,212$ atau berarti $21,20 \%$ (lampiran 22). Selanjutnya dicari persamaan regresi untuk mengetahui hubungan antara kelekatan orang tua dengan anak terhadap kecerdasan emosional remaja laki-laki kelas VIII SMPN 2 Pagedangan Tangerang. Analisis regresi linier sederhana terhadap pasangan data penelitian antara kelekatan orang tua dengan anak terhadap kecerdasan emosional remaja laki-laki kelas VIII SMPN 2 Pagedangan Tangerang menghasilkan koefisien regresi sebesar 0,60 dan konstanta sebesar 19,93. Dengan demikian bentuk hubungan antara kelekatan orang tua dengan anak terhadap kecerdasan emosional remaja laki-laki memiliki persamaan regresi $\hat{Y}=19,93+0,60 X$. Hasil perhitungan uji keberartian regresi menunjukan nilai Fhitung sebesar 29,73 dan nilai Ftabel sebesar 3,931. Berdasarkan hasil tersebut maka hipotesis $\mathrm{H}_{\mathrm{o}}$ ditolak, sebab Fhitung > Ftabel, sehingga dapat disimpulkan bahwa arah regresi berarti.

\section{KESIMPULAN}

Berdasarkan pengolahan deskriptif, pengolahan data statistik dan analisis data yang telah diuraikan sebelumnya maka dapat ditarik kesimpulan sebagai berikut:

1. Berdasarkan skor masing-masing responden, kelekatan orang tua dengan anak siswa remaja laki-laki di SMPN 2 Pagedangan Tangerang memiliki indikator dominan atau indikator yang memiliki persentase sumbangan terbesar adalah indicator kepercayaan, yang kedua adalah indikator keterasingan, dan yang terkecil adalah indikator komunikasi.

2. Berdasarkan skor masing-masing responden, kecerdasan emosional siswa remaja laki-laki di SMPN 2 Pagedangan Tangerang memiliki indikator dominan atau indikator yang memiliki persentase sumbangan terbesar adalah indikator mengenali emosi diri, yang kedua adalah indikator mengenali emosi orang lain (empati), dan yang terkecil adalah indikator mengelola emosi diri.

3. Perhitungan korelasi menunjukan rhitung sebesar 0,46 dan rtabel yaitu 0,254 . Berdasarkan hal tersebut maka rhitung lebih besar dari rtabel $(0,46>0,254)$. Maka terdapat hubungan positif antara kelekatan orang tua dengan anak terhadap kecerdasan emosional remaja laki-laki.

4. Perhitungan uji " $\mathrm{t}$ " korelasi menunjukan thitung sebesar 6,15 dan ttabel 1,659. Dengan demikian thitung lebih besar dari ttabel $(6,15>1,659)$. Hal ini menunjukan bahwa kedua variabel mempunyai hubungan yang signifikan.

5. Perhitungan koefisien determinasi sebesar $21.20 \%$ menunjukan bahwa kecerdasan emosional remaja laki-laki ditentukan oleh kelekatan orang tua dengan anak, sedangkan $78,80 \%$ ditentukan oleh faktor lain, seperti pola asuh orang tua, interaksi dengan teman sebaya, dan lain sebagainya.

6. Uji hipotesis penelitian mengenai hubungan kelekatan orang tua dengan anak terhadap kecerdasan emosional remaja laki-laki kelas VIII SMPN 2 Pagedangan Tangerang menunjukan bahwa terdapat hubungan yang positif dan berarti diantara keduanya.

Berdasarkan kesimpulan yang telah dikemukakan maka untuk menerapkan kelekatan orang tua dengan anak yang tepat khususnya terhadap kecerdasan emosional anak atau remaja lakilaki peneliti akan memaparkan beberapa saran, yaitu sebagai berikut:

1. Orang tua agar meningkatkan kualitas komunikasi serta mengurangi rasa keterasingan yang dirasakan oleh remaja laki- laki dengan cara menciptakan qualitytime keluarga. Qualitytime sendiri dimaksudkan sebagai waktu yang berkualitas dimana orang tua dengan remaja laki-laki dapat saling bertukar cerita mangenai apa yang telah atau sedang mereka alami. Waktu yang ditentukan dapat disesuaikan dengan keadaan dan situasi keluarga, namun semakin sering dan teratur waktu yang ditentukan maka komunikasi akan semakin baik.

2. Pihak sekolah agar menciptakan program atau kegiatan yang bertujuan untuk meningkatkan 
kecerdasan emosional anak. Program tersebut dapat berupa bimbingan kelompok yang dilakukan guru kesiswaan atau bimbingan konseling kepada siswanya, yang bertujuan untuk mengasah dan meningkatkan kecerdasan emosional siswa.

\section{DAFTAR PUSTAKA}

Ali, M., \&Asrori, M. 2012. Psikologi R emaja: Perkembangan Peserta Didik. Jakarta: Bumi Aksara.

Ancok, D. 2004. Psikologi Terapan Remaja dan Keterasingan. Yogyakarta: Darussalam.

Anganti, N. R. A., Purwandari, E., \& Purwanto, Y. 2010. Pola Delinquency Penyalahguna Napza di Surakarta. Laporan Penelitian Fundamental Research Dikti.

Arikunto, S. 2008. Dasar-Dasar Evaluasi Pendidikan. Jakarta: Bumi Aksara.

[BKKBN] Badan Koordinasi Keluarga Berencana Nasional. Remaja Genre dan Perkawinan Dini. http://www.bkkbn.go.id/. Diakses pada tanggal 7 Juli 2014.

[BKKBN] Badan Koordinasi Keluarga Berencana Nasional. 2013. Cara Ampuh Berkomunikasi dengan Remaja. http://www.jdih.net/web bppkb/. Diakses pada tanggal 7 Juli 2014.

Baron, A. R., \& Byrne, D. 2003. Psikologi Sosial. Jilid 2. (terjemahan Ratna Djuwita, dkk,). Jakarta: Erlangga.

Dewi, A. A. A. \& Valentina, T. C. 2013. Hubungan Kelekatan Orang Tua- Remaja dengan Kemandirian pada Remaja SMKN 1 Denpasar. Jurnal Psikologi Udayana, Vol. 1, no. 1, 181-189.

Effendi, S. 2012. Metode Penelitian Survey. Jakarta: LP3ES.

Goleman, D. 2000. Emotional Intelligence: Mengapa EI lebih penting daripada IQ (Alih Bahasa: T. Hermaya). Jakarta: PT Gramedia Pustaka Utama.

Hapsariyanti, D. 2006. Hubungan Kecerdasan Emosional dengan Penyesuaian Diri dalam Perkawinan pada Pasangan yang Baru Menikah Selama Tiga Tahun. Kumpulan Jurnal Fakultas Psikologi Universitas Gunadarma.

Hermasanti, W. K. 2009. Hubunganantara Pola Kelekatan dengan Kecerdasan Emosi pada Remaja Siswa Kelas XI SMAN 1 Karanganyar. Skripsi. (Tidak Diterbitkan). Surakarta: Fakultas Psikologi Universitas Sebelas Maret Surakarta.

Hurlock, E. B. 2004. Psikologi Perkembangan: Suatu Pendekatan Sepanjang Rentang Kehidupan (Terjemahan Instiwidayanti dan Soedjarwo). EdisiKelima. Jakarta: Erlangga. 2005b P erkembangan Anak. Edisi Keenam. Jilid 2. Jakarta: Erlangga.

Kartono, K. \& Dali, G. 2003. Kamus Psikologi. Bandung :Pionir Jaya.

Kuswanto, D. 2012. Statistik untuk pemula dan orang. Jakarta: Laskar Aksara.

Malik, M. A. 2003. Pengaruh Kualitas Interaksi Orang Tua dan Anak dengan Konsep Diri terhadap Kecerdasan Emosi pada Siswa SMU di Makasar. Journal Intelectual, Volume 1 no 1, 33 50 .

Margono, S. 2009. Metodologi Penelitian Pendidikan: komponen MKDK. Jakarta: Rineka Cipta.

Monks, F. J., Knoers, A. M. P., \&Haditono, S. R. 2004. Psikologi Perkembangan Pengantar Dalam Berbagai Bagiannya. Yogyakarta: Gadjah Mada University Press.

Mu'tadin, Z. 2002. Mengenal Kecerdasan Emosional Remaja. http://www.epsikologi.com. diakses 11 Februari 2014

Papalia, D. E., Old, S. W., Feldman, \& R. D. 2008. Human Development (terjemahan A. K. Anwar). Jakarta: Prenada Media Group.

Patty, F., Woeryo, K., Syam, M. N., Ardhana, W.,Saleh, A. I. 1982. Pengantar Psikologi Umum. Surabaya: Usaha Nasional.

Purwandari, E. 2011. Keluarga, Kontrol Sosial, dan "Strain": Model Kontinuitas Delinquency Remaja. Humanitas, Vol. VIII No. 1, januari 2011

Putri, M. 2012. Profil Motif Berprestasi Siswa SMP Berdasarkan Urutan Kelahiran Dalam Keluarga dan J enis Kelamin [Skripsi]. Bandung: Universitas Pendidikan Indonesia.

Rosdiana, S. 2011. Faktor-Faktor Psikologis yang Mempengaruhi Intensi Merokok Pada Remaja 
[Skripsi]. Jakarta: Fakultas Psikologi, Universitas Islam Negeri Syarif Hidayatullah.

Santrock, J. W. 2003. AdolescencePerkembanganRemaja (terjemahan Adelar, S. B., dan Saragih, S). Jakarta: Erlangga.

2011. Masa Perkembangan Anak. Edisi 11. Jilid 2 (terjemahan Pakpahan, Verawaty

dan Anugraheni, Wahyu). Jakarta: Salemba Humanika.

Sarwono, S. 2000. Psikologi Remaja. Jakarta: PT. Raja Grafindo.

. 2002. Kecerdasan Emosi. Jurnaln Psikologi Indonesia. Diperoleh dari

www.sarlito.hyperphp.com. Diakses pada 1 Februri 2014

Siregar, R. 2003. Sibling Rivalry Remaja u dari Urutan Kelahiran dan Jenis Kelamin [Skripsi].

Semarang: Fakultas Psikologi Universitas Katolik Soegijapranata. Sudjana. 2005. Metoda

Statsitika. Bandung: Tarsito.

Sugiono. 2011. Metode Penelitian Kuantitatif, Kualitatifdan R \& D. Bandung: ALFABETA. 2008. Metode Penelitian Bisnis. Bandung: ALFABETA.

Ulpatusalicha. 2009. Dampak Perceraian Orang Tua Terhadap Perkembangan Emosional Anak. http://digilib.uin-suka.ac.id/. Diakses tangga 7 Juli 2014.

Yessy. 2003. Hubungan Pola Attachment dengan Kemampuan Menjalin Relasi Pertemanan pada Remaja. Jurnal Psikologi, Vol. 12, no. 2, 1-12. 